\title{
PENGUATAN MANAJEMEN KEPEMIMPINAN KEPALA MADRASAH DALAM MENINGKATKAN KUALITAS PENDIDIKAN
}

\author{
Abdul Kadir \\ IAIN Kendari \\ Email: kadirbaruta@iainkendari.ac.id
}

\begin{abstract}
Leadership is the art of influencing people, the art of moving people by utilizing resources to achieve goals. This understanding gives two meanings that need to be in the expalin. First, art, if leadership is an art, then it can be certain that everyone has their own way of expressing it. Second, others, if leadership has to involve others, then its main obligation is to observe, pay attention to the condition of others. Therefore, leadership is a discourse between who we are and how others are. This understanding provides logical consequences that the way, style of leadership type model will differ from one person to another. The effectiveness of leadership depends on how one's leadership style is adapted to circumstances or situations. If the style used by the leader suits the situation, then his leadership will be effective and vice versa.
\end{abstract}

Keywords: Leadership of madrasah head, Quality of Education

\begin{abstract}
Abstrak
Kepemimpinan merupakan seni memengaruhi orang, seni menggerakan orang dengan memanfaatkan sumberdaya demi mencapai tujuan. Pemahaman ini memberikan dua makna yang perlu diuraikan. Pertama, seni, jika kepemimpinan merupakan seni, maka dapat dipastikan setiap orang memiliki cara tersendiri untuk mengekspresikannya. Kedua, orang lain, jika kepemimpinan harus melibatkan orang lain, maka kewajiban utamanya adalah mengamati, memperhatikan kondisi orang lain. Oleh sebab itulah maka kepemimpinan merupakan suatu diskurusus antara siapa diri kita dan bagaimana orang lain. Pemahaman ini memberikan konsekwensi logis bahwa cara, gaya model tipe kepemimpinan akan berbeda antara satu orang dengan lainnya. Efektifitas kepemimpinan tergantung pada bagaimana gaya kepemimpinan seseorang disesuaikan dengan keadaan atau situasi. Jika gaya yang digunakan oleh pemimpin sesuai dengan situasi, maka kepemimpinannya akan efektif dan begitu sebaliknya.
\end{abstract}

Kata Kunci: Kepeimipinan kepala madrasah, Kualitas pendidikan

\section{PENDAHULUAN}

Pemimpin dan kepemimpinan (leadership) merupakan dua unsur yang tidak bisa dipisahkan dan menempati posisi yang sangat penting dalam sebuah organisasi. Jika organisasi diibaratkan seorang manusia, maka pemimpin adalah otaknya dan kepemimpinan adalah hatinya. Sehingga, sebaik apapun bentuk fisik 
manusia tersebut jika otak dan hatinya tidak berfungsi dengan baik dia tidak akan bisa berperan dengan baik dalam kehidupannya. Demikian pula organisasi, ia tidak akan pernah bisa efektif jika unsur pemimpin dan kepemimpinan tidak berfungsi sebagaimana mestinya. Dengan demikan tidaklah mengherankan jika kedua istilah tersebut, khususnya kepemimpinan, telah menarik perhatian banyak orang untuk mengkajinya lebih dalam, bahkan telah melalui beberapa penelitian ilmiah. Berbagai upaya dilakukan untuk mengungkap tentang efektivitas kepemimpinan. Aneka pertanyaan pun bermunculan, seperti mengapa seseorang bisa menjadi pemimpin yang sukses sedangkan yang lainnya tidak, apa saja faktor yang menentukan cara pemimpin bertindak, bagaimana ciri-ciri seorang pemimpin yang baik, dan sebagainya yang kesemuanya ditujukan untuk memahami hakikat kepemimpinan. Upaya menciptakan sebuah lembaga pendidikan yang bermutu sebagaimana yang diharapkan banyak orang atau masyarakat bukan hanya menjadi tanggungjawab sekolah, tetapi merupakan tanggungjawab dari semua pihak termasuk didalamnya orang tua dan dunia usaha sebagai customer internal dan eksternal dari sebuah lembaga pendidikan. ${ }^{1}$

Dalam kaitannya dengan organisasi yang kita kenal pada saat ini, baik itu organisasi sosial maupun yang lainnya. Bercermin dari apa yang telah digariskan Rasulullah SAW di atas, maka setiap orang yang memimpin sebuah organisasi ia berkewajiban membawa organisasinya serta orang-orang yang terlibat di dalamnya mencapai tujuan serta ia juga berkewajiban menjaga eksistensi organisai tersebut. Apalagi organisasi tersebut hidup di tengah-tengah kancah perubahan yang terjadi secara terus-menerus, persaingan yang semakin meningkat, serta menghadapi situasi kerja dan pasar yang semakin beragam. Sehingga, tanggung jawabnya pun akan semakin berat dan besar. Mau tidak mau pemimpin organisasi harus menyesuaikan organisasi dengan perubahan dan perkembangan situasi tersebut.

1 Asnawan, Enhancement Integrated Quality Management in Islamic Education Institutions (Peningkatan Manajemen Mutu Terpadu di Lembaga Pendidikan Islam ), Vol. 1, No. 1, January 2021, View of Enhancement Integrated Quality Management in Islamic Education Institutions (attractivejournal.com) 
Demikian pula dengan kesulitan-kesulitan yang dihadapi oleh seorang pemimpin karena mengelola suatu organisasi pada dasarnya bukanlah suatu perkara yang mudah, karena untuk melakukan pengembangan pasti ada beberapa hal yang mengalami perubahan. Padahal tidak semua orang menyukai terjadinya perubahan, sehingga tidak jarang kita temukan munculnya reaksi emosional baik secara rasional maupun irrasional dari berbagai pihak di saat terjadinya perubahan. Penolakan itu terjadi secara umum setidaknya didasari oleh empat alasan. Pertama, kepentingan pribadi yang picik, mereka khawatir kehilangan sesuatu yang bernilai bagi mereka. Baik itu kehilangan kekuasaan, sumber daya, kebebasan mengambil keputusan, persahabatan, maupun prestise. Mereka lebih memperdulikan kepentingan pibadi daripada kepentingan organisasi. Kedua, salah pengertian dan kurang percaya. Jika orang tidak sepenuhnya memahami mengapa terjadi perubahan dan apa pengaruh dar perubahan tersebut. Ketiga, penilaian yang berbeda. Seringkali terjadi perbedaan pandangan dalam menyikapi perubahan yang terjadi. Para pemrakarsa memandang perubahan yang dilakukan sebagai hal yang positif, sedangkan yang lainnya memandang sebagai sesuatu yang negatif bahkan hal yang mengancam eksistensinya di organisasi. Keempat, toleransi yang rendah terhadap perubahan. Hal ini dikarenakan, selain untuk menyelamatkan diri dari pengaruh terjadinya perubahan tersebut, mereka takut tidak bisa lagi mengembangkan keahlian baru untuk melaksanakan pekerjaan dengan baik.

Menghadapi kondisi demikian, dibutuhkan seorang pemimpin yang tidak hanya menduduki posisi sebagai pimpinan, tetapi pemimpin yang benar-benar memiliki jiwa kepemimpinan (leadership) yang berkualitas. Dalam hal ini Beach dan Reinhartz ${ }^{2}$ mengidentifikasi beberapa ciri kepemimpinan yang berkualitas yang seharusnya dimiliki oleh seorang pimpinan:

1. Memiliki kemampuan untuk menciptakan budaya organisasi yang akan menjadi pedoman bagi seluruh anggotanya. Dengan kemampuan tersebut, seorang pemimpin dapat mempengaruhi persepsi, pandangan

\footnotetext{
2 Judy Reinhartz dan Don M. Beach, Educational Leadership: Changing Schools, Changing Roles, Pearson Education, Inc: USA, 2004, hal. 14.
} 
dan cara kerja orang-orang yang ada di dalam organisasi tersebut, karena budaya organisasi, menurut Robbins, ${ }^{3}$ merupakan suatu sistem pengertian bersama yang dipegang oleh anggota-anggota suatu oraganisasi, yang akan membedakan organisasi tersebut dari organisasi lainnya. Sistem pengertian bersama inilah yang akan menjadi nilai bagi sebuah organisasi.

2. Memiliki kemampuan mempergunakan kecakapan interpersonal dalam rangka membangun kepercayaan dan kerjasama dengan pihak lain. Kecakapan interpersonal yang dimaksud adalah kecakapan dalam membina hubungan atau bersosialisasi dengan orang lain. ${ }^{4}$ Dengan kecakapan tersebut seorang pemimpin akan lebih mudah membina hubungan baik dengan para bawahan dan rekan kerjanya serta dalam menjalin kerjasama dengan pihak lain.

3. Memiliki kemampuan untuk mengkomunikasikan dan menyampaikan misi, tujuan dan strategi-strategi. Kemampuan berkomunikasi bukan hanya berarti kemampuan menyampaikan informasi dan ide-ide kepada orang lain/bawahan, tetapi juga kemampuan untuk memahamkan apa yang disampaikan. Sebesar apapun ide yang dimilki tetapi jika tidak dipahami orang lain maka tidak akan berarti apa-apa.

4. Memiliki kemampuan untuk menunjukkan integritas pribadi serta tanggungjawab dalam berinteraksi dengan pihak lain.

5. Memiliki kemampuan mendiagnosa permasalahan, memilih prosedur berdasarkan pertimbangan yang wajar serta kemungkinan resiko yang ditimbulkannya

6. Memiliki kemampuan untuk bekerjasama untuk mencapai tujuan.

Dengan kemampuan-kemampuan tersebut diharapkan pemimpin akan mampu membawa organisasi menggapai kesuksesan. Karena keberhasilan dan kesuksesan serta kualitas sebuah organisasi, atau setiap keloimpok dalam organisasi sangat tergantung pada kualitas kepemimpinannya. Seorang pemimpin

${ }^{3}$ Stephen P. Robbins, Prinsip-prinsip, hal. 279

${ }^{4}$ Lihat Gordon Dryden dan Jeannette Vos, Revolusi Cara Belajar: Sekolah Masa Depan, Bandung, Kaifa, 2000 , hal 345. 
yang berhasil adalah pemimpin yang mampu mengantisipasi perubahan, dengan sekuat tenaga memanfaatkan kesempatan, memotivsi pengikut mereka untuk mencapai produktivitas yang tinggi, mengoreksi kinerja yang buruk, dan mendorong organisasi ke arah sasaran-sasarannya. Dan yang terpenting bagi seorang pemimpin adalah kemampuannya untuk mengkoordinasikan dan mengendalikan orang-orang yang berada dibawahnya menuju ke arah tujuan atau sasaran yang diinginkan.

Pemimpin pada dasarnya merupakan tokoh utama yang sangat menentukan kemajuan dan keunggulan kompetitif organisasi. Ia tidak hanya berfungsi sebagai manajer yang efektif, namuan sekaligus berperan sebagai pemimpin transformasional. Pemimpian diharapkan dapat membawa organisasi mencapai kinerja yang melebihi espektasi secara berkelanjutan. Hal inilah yang banyak menuntut terhadap pemimpin untuk menguasai beragam kemampuan, baik yang bersifat personal maupun institusional. Dalam iklim usaha yang tidak menentu, sangat penting bagi pemimpin untuk dapat mengendalikan organisasi ke arah yang jelas dan konsisten. Mereka harus secara berani mengelola ketidak pastian serta menangani kondisi sekarang secara efektif, kemudian secara simultan mengantisipasi dan merespon tuntutan di masa yang akan datang. Oleh karena itu, pemimpin mestinya selalu mengekspresikan, menjelaskan, mengembangkan dan bahkan merevisi arah dan tujuan organisasi untuk kepentingan efektifitas dan capaian yang optimal. Langkah ini sebagai sebuah metode untuk dapat mencapai hasil yang baik di akhir proses berjangka. Melalui uraian ini, penulis hendak menjelaskan tentang bagaiamana potret kepemimpinan kepala Madrasah efektif yang dapat menjamah terhadap ragam dimensi kepemimpinan. Mulai dari aspek leadership hingga aspek manajerial. Baik yang berkaitan dengan kapabilitas personal, interlektual, relasional dan institusional. Karena, sejatinya menjadikan suatu lembaga pendidikan bermutu bukanlah perkara sulit, karena hanya membutuhkan tiga pendekatan, yaitu Rasa, Rasio dan Do'a. Dengan rasa seorang pemimpin dapat bertindak humanis, dengan rasio seorang pemimpin menjadi visioner dan implementatif, dengan do'a seorang pemimpin mengenal kepasrahan. Pentingnya penguatan manajemen kepemimpinan pendidikan Islam adalah suatu 


\section{Abdul Kadir}

proses pengelolaan lembaga pendidikan Islam secara Islami dan berkelanjutan dengan cara mensiasati sumber sumber belajar yang mempuni dan hal-hal lain yang terkait untuk mencapai tujuan pendidikan Islam secara efektif dan efisien. $^{5}$

\section{PEMBAHASAN}

\section{Kepemimpinan Pendidikan}

Untuk mendefinisikan istilah kepemimpinan (leadership) secara tepat bukanlah hal yang mudah. Hal ini, menurut Janda dikarenakan istilah kepemimpinan diambil dari kata-kata yang umum dipakai dan merupakan gabungan dari kata ilmiah yang, menurut Bennis, belum ada yang tuntas mendefinisikannya. Akibatnya, istilah kepemimpinan selalu kabur karena artinya yang kompleks dan mendua. Begitu sulitnya menentukan definisi yang tepat tentang kepemimpinan, sampai-sampai Greenberg dan Baron ${ }^{6}$ memandang kepemimpinan serupa dengan cinta, dalam artian banyak orang yang meyakini bahwa ia bisa memahami tentang kepemimpinan tetapi menemukan kesulitan ketika mencoba mendefinisikannya. Disamping itu, menurut Yukl, digunakannya istilah-istilah lain seperti kekuasaan, wewenang, manajemen, administrasi, pengendalian, dan supervisi yang juga menjelaskan hal yang sama dengan kepemimpinan semakin menambah kebingungan tersebut. ${ }^{7}$ Sehingga tidak mengherankan jika kita menemukan begitu banyak definisi tentang kepemimpinan, sampai-sampai Ralph M. Stodgill ${ }^{8}$ setelah melakukan kajian mendalam terhadap literatur kepemimpinan berkesimpulan bahwa "terdapat definisi mengenai kepemimpinan yang berbeda hampir sebanyak orang yang berusaha mendefinisikan konsep tersebut."

5 Abd. Wahib, Urgensitas Manajemen Lembaga Dalam Meningkatkan Kepercayaan Masyarakat, Jurnal Falasifa, Vol. 11 Nomor 1 Maret 2020, Vol 11 No 1 (2020): MARET | FALASIFA : Jurnal Studi Keislaman (inaifas.ac.id)

\footnotetext{
${ }^{6}$ Lihat dalam Judy Reinhartz dan Don M. Beach, Educational Leadership: Changing Schools, Changing Roles (USA: Pearson Education, Inc., 2004), hal. 3.

${ }^{7}$ Gary Yukl, Kepemimpinan dalam Organisasi (Jakarta: PT. Indeks, 2005), hal.3.

${ }^{8}$ James AF Stoner dkk, Manajemen, Jilid II (Jakarta: PT Prenhallindo, 1996), hal.161.
} 
Stephen P Robbins mendefinisikan kepemimpinan sebagai kemampuan mempengaruhi suatu kelompok ke arah pencapaian tujuan. ${ }^{9}$ Gibson dkk. mendefinisikannya sebagai upaya penggunaan jenis pengaruh bukan paksaan untuk memotivasi orang-orang mencapai tujuan tertentu. ${ }^{10}$ Demikian pula definisi yang dikemukakan Stoner dkk., ${ }^{11}$ tampaknya senada dengan definisi sebelumnya, menurut mereka kepemimpinan adalah proses mengarahkan dan mempengaruhi aktivitas yang berkaitan dengan pekerjaan dari anggota kelompok.

Dari beberapa definisi tantang kepemimpinan di atas dapat dipahami bahwa kepemimpinan merupakan proses yang berisi rangkaian kegiatan yang melibatkan sekelompok orang yang. Dalam proses tersebut terjadi aktivitas mempengaruhi, memotivasi, menggerakkan dan mengarahkan pikiran dan perasaan pihak lain ke arah tujuan yang telah disepakati bersama. Definisi-definisi tentang kepemimpinan tersebut, menurut Stoner dkk., setidaknya mengandung empat implikasi penting tentang kepemimpinan, yaitu: pertama, kepemimpinan melibatkan orang lain. Kepemimpinan tidak bisa berdiri sendiri tapi harus ada orang lain yang terlibat didalamnya, baik sebagai karyawan atau pengikut yang akan menerima pengarahan dari pimpinan; kedua, kepemimpinan mengharuskan distribusi kekuasaan. Dalam kepemimpinan, seorang pemimpin tidak seharusnya memegang kekuasaan secara penuh, tetapi ia harus membagi-bagi kekuasaannya dengan anggota kelompok di bawahnya. Sekalipun demikian, ia tetap mempunyai kekuasaan lebih besar daripada yang lainnya; ketiga, kepemimpinan harus mempunyai pengaruh. Tanpa pengaruh, kepemimpinan tidak akan berarti apa-apa. Pemimpin yang memiliki kemampuan mempengaruhi anggota kelompoknya akan lebih mudah mengarahkan mereka ke arah tujuan yang ingin dicapai; keempat, kepemimpinan berkaitan dengan nilai. Dengan kata lain bahwa seorang pemimpin haruslah bermoral, pemimpin yang mengenyampingkan aspek moral dalam kepemimpinannya cenderung akan bersikap melanggar aturan dan etika-etika yang ada.

\footnotetext{
9 Stephen P. Robbins, Prilaku Organisasi: Konsep, Kontroversi, Aplikasi, Jilid 2 (Jakarta: PT Prenhallindo, 1996), hal.39.

${ }^{10}$ James L. Gibson, et.al, Organisasi, Jilid 1 (Jakarta: Erlangga, 1996), hal.334.

${ }^{11}$ Lihat James AF Stoner, hal. 161.
} 
Seorang pemimpin biasanya mempunyai sifat, kebiasaan, temperamen watak dan kepribadian sendiri yang unik dan khas. Kekhasannya gaya hidupnya tersebut sedikit banyak pasti akan berpengaruh dan mewarnai perilaku kepemimpinannya. Sehingga muncullah beberapa tipe atau gaya kepemimpinan yang menurut W. J Reddin, sebagaimana dikutip Kartini Kartono, ${ }^{12}$ membentuk tiga pola dasar, yaitu:

- Kepemimpinan yang berorintasikan tugas (task orientation)

- Kepemimpinan berorientasikan hubungan kerja (relationship orientation)

- Kepemimpinan beroriemtasikan hasil yang efektif (effectives orientation)

Seorang pemimpin yang berorientasikan pada tugas biasanya sangat menekankan pada tugas yang diemban oleh bawahan. Hal ini didasari asumsi bahwa tugas pemimpin adalah mendorong agar setiap anggota melaksanakan tugas masing-masing secara maksimal, sehingga terkadang melupakan aspekaspek lainnya dalam organisasi seperti aspek kemanusiaan dan kerjasama. Kepemimpinan yang berorientasi pada kerjasama biasanya lebih mengutamakan hubungan manusiawi antar anggotanya. Ia memandang nilai-nilai organisasi sebagai nilai-nilai luhur yang perlu dirancang dan ditetapkan oleh seluruh staf dengan harapan staf mempunyai rasa memiliki dan komitmen dalam pelaksanaannya. Kelemahan gaya kepemimpinan ini karena terlalu menekankan pada hubungan manusiawi yang efektif terkadang berakibat perhatian terhadap tugas dan hasil melemah.

Kepemimimpinan yang berorientasi pada hasil biasanya berpandangan bahwa hasil sebagai hal yang utama dalam organisasi. Ia tidak terlalu mementingkan bagaimana cara yang dilakukan oleh para bawahan yang penting hasil yang ditargetkan tercapai.

Dari ketiga pola dasar kepemimpinan ini melahirkan beberapa tipe kepemimpinan yang diantaranya:

\footnotetext{
${ }^{12}$ Kartini Kartono, Pemimpin dan Kepemimpina, (Jakarta: PT. Raja Grafindo Persada, 1998), hal.28.
} 
1. Tipe otokratis; biasanya keras, diktatoris, keras kepala, mau menang sendiri, berorientasi pada tugas, dan sombong.

2. Tipe otokrasi yang bijak; biasanya lebih tertib, ahli dalam mengorganisir, dan ketat dalam menerapkan peraturan-peraturan.

3. Tipe birokrat; biasanya kaku, patuh pada peraturan dan norma-norma, berdisiplin dank eras.

4. Tipe pelindung; biasanya terbuka, penolong, lembut hati, dan ramah tamah.

5. Tipe pembangun; biasanya kreatif, inovatif, dan distributor tugas yang baik.

6. Tipe eksekutif; biasanya memperhatikan pada kualitas, berwawasan, percaya pada kemampuan bawahan, motivator dan terbuka.

7. Tipe kompromis; biasanya plin-plan, berpandangan sempit, penjilat, dan transaksional.

8. Tipe pembelot; biasanya bermoral rendah, menghindar dari tugas dan tanggung jawab, tidak loyal dan sukar ditebak. ${ }^{13}$

Untuk menjadi seorang pemimpin bagi sekelompok orang, apalagi dalam sebuah organisasi, tidak cukup hanya mengandalkan jabatan yang dipegangnya. Setidaknya ia harus memiliki nilai lebih daripada orang-orang yang dipimpinnya. Beach dan Reinhartz ${ }^{14}$ mengidentifikasi beberapa ciri kepemimpinan yang berkualitas yang seharusnya dimiliki oleh seorang pimpinan:

1. Memiliki kemampuan untuk menciptakan budaya organisasi yang akan menjadi pedoman bagi seluruh anggotanya. Dengan kemampuan tersebut, seorang pemimpin dapat mempengaruhi persepsi, pandangan dan cara kerja orang-orang yang ada di dalam organisasi tersebut, karena budaya organisasi, menurut Robbins, ${ }^{15}$ merupakan suatu sistem pengertian bersama yang dipegang oleh anggota-anggota suatu oraganisasi, yang akan membedakan organisasi tersebut dari organisasi lainnya. Sistem pengertian bersama inilah yang akan menjadi nilai bagi sebuah organisasi.

\footnotetext{
${ }^{13}$ Ibid., hal.30.

14Judy Reinhartz dan Don M. Beach, hal. 14.

${ }^{15}$ Stephen P. Robbins, Prinsip-Prinsip Prilaku Organisasi (Jakarta: Erlangga, 2002), hal.279.
} 
2. Memiliki kemampuan mempergunakan kecakapan interpersonal dalam rangka membangun kepercayaan dan kerjasama dengan pihak lain. Kecakapan interpersonal yang dimaksud adalah kecakapan dalam membina hubungan atau bersosialisasi dengan orang lain. ${ }^{16}$ Dengan kecakapan tersebut seorang pemimpin akan lebih mudah membina hubungan baik dengan para bawahan dan rekan kerjanya serta dalam menjalin kerjasama dengan pihak lain.

3. Memiliki kemampuan untuk mengkomunikasikan dan menyampaikan misi, tujuan dan strategi-strategi. Kemampuan berkomunikasi bukan hanya berarti kemampuan menyampaikan informasi dan ide-ide kepada orang lain/bawahan, tetapi juga kemampuan untuk memahamkan apa yang disampaikan. Sebesar apapun ide yang dimiliki tetapi jika tidak dipahami orang lain maka tidak akan berarti apa-apa.

4. Memiliki kemampuan untuk menunjukkan integritas pribadi serta tanggungjawab dalam berinteraksi dengan pihak lain. Pemimpin yang memiliki integritas dan tanggung jawab yang tinggi akan menumbuhkan kepercayaan, baik dari bawahan maupun rekan-rekan kerjanya.

5. Memiliki kemampuan mendiagnosa permasalahan, memilih prosedur berdasarkan pertimbangan yang wajar serta kemungkinan resiko yang ditimbulkannya.

6. Memiliki kemampuan untuk bekerjasama untuk mencapai tujuan. Seorang pemimpin tidak akan pernah bisa bekerja sendiri, ia hanya akan disebut pemimpin saat ia bersama anggota kelompok yang dipimpinnya, karena itu seorang pemimpin harus mampu membangun kerjasama dalam organisasi yang dipimpinnya. Selain itu, dengan semakin kompleks dan beragamnya kehidupan pada saat ini, pemimpin organisasi juga perlu membina hubungan dengan organisasi lainnya.

${ }^{16}$ Lihat Gordon Dryden dan Jeannette Vos, Revolusi Cara Belajar: Sekolah Masa Depan (Bandung: Kaifa, 2000), hal.345. 


\section{Konsep Kepemipinan Kepala Madrasah Efektif}

\section{Kepemimpinan Efektif}

Secara definitif, kepemimpinan efektif merupakan sistem atau pola kepemimpinan yang secara kuat memperjuangkan idealisme yang ingin dicapai. ${ }^{17}$ Pemahaman ini mengharuskan akan tersedianya seorang pemimpin yang mempu menggunakan wewenang yang dimilikinya secara profesional, pemimpin yang mampu merumuskan sasaran yang hendak dicapai dengan jelas, terukur dan sesuai dengan sumber daya yang dimiliki. Di samping itu, pemimpin tersebut juga harus dapat mengkomunikasikan ide, gagasan perubahan yang hendak dicapai terhadap bawahannya, serta dapat menyelesaikan persoalan dengan pertimbangan rasio dan rasa.

Dalam menjalankan tugas kepemimpinannya, seorang pemimpin harus dapat menjadi model bagi seluruh bawahannya, mitra pendukung yang menjadi bagian dalam organisasinya. Ia harus mampu menjadi tumpuan elemen organisasi yang dalam dirinya tercermin karakter dan kompetensi secara terpadu. Karakter berkaitan dengan siapa dirinya sebagai pribadi, sedangkan kompetensi adalah berkaitan dengan apa yang bisa ia lakukan sebagai seoarang pimpinan. Berkaitan dengan ini, Covey membagai peran pemimpin menjadi tiga macam: ${ }^{18}$

a. Path Finding (Pencarian Alur) : Peran yang harus dimainkan oleh pemimpin dalam rangka menentukan visi dan misi bagi organisasinya untuk menggiring akitfitas organisasi pada fokus yang sama.

b. Aligning (Penyelaras) : peran yang harus dijalankan untuk memastikan bahwa sistem dan proses oprasional organisasi telah sesuai, mendukung terhadap tercapainya visi dan misi yang telah ditetapkan.

c. Empowering (Pemberdaya) : Peran untuk menggarakkan semangat dalam diri orang-orang yang dipimpinnya, memaksimalkan potensi, kreatifitas laten yang dimiliki bawahannya untuk dapat mengerjakan tugas-tugas manajerialnya sesuai dengan prinsip-prinsip yang telah disepakati.

${ }^{17}$ Veithzal Rivai, Pemimpin dan Kepemimpinan dalam Organisasi, (Jakarta: Rajawali Press, 2014), hal. 150

18 Veithzal Rivai, Education Management (Jakarta: Rajawali Press, 2009), hal. 746 
Teori yang dikemukakan oleh Covey di atas, telah mengakomodir dua aspek kepemimpinan, yaitu leadership dan manajerial. Sehingga, dapat dikatakan bahwa pemimpin yang dapat menjalankan peran sebagaimana di atas, maka efekfitas sistem kepemimpinannya dapat terwujud. Kepastian akan terwudunya sistem kepemimpinan ini harus diimbangi dengan kepribadian pemimpin yang secara instingtif dapat memberikan keputusan-keputusan yang cepat dan tepat pada kondisi-kondisi tertentu.Tiga peran kepemimpinan di atas juga selaras dengan konsep yang dikemukakan oleh Halpin, Blake dan Mouton yang menyatakan bahwa kepemimpinan yang efektif harus didukung oleh dua dimensi kepemimpinan yang seimbang, yaitu struktur kelembagaan dan Konsiderasi. Menurutnya, secara kelembagaan, pemimpin harus dapat mendefinisikan dan menyusun pola interaksi kelompok dalam rangka mencapai tujuan. Ia juga harus dapat mengorganisasi anggotanya sesuai dengan postur organisasinya secara ramping dan fungsional. Sedangkan secara konsiderasi, pemimpin diharuskan pada membangun hubungan kerjasama dengan bawahannya disertai adanya perhatian terhadap kebutuhan sosial, emosi untuk menunjang kepuasaan kerja. Konsiderasi ini menuntut adanya komunikasi dua arah yang harus dilakukan oleh pemimpin. Pola inilah yang menyebabkan terciptasinya partisipasi aktif, hubungan manusiawi antar organ dalam organisasi. ${ }^{19}$

Sebagai faktor yang berkonstribusi terhadap kepemimpinan efektif di lembaga pendidikan, kinerja kepala Madrasah harus dimenifestasikan dalam tatanan kinerja pada bidang pengelolaan kurikulum, KBM, pengelolaan pembiayaan, sarana dan prasarana serta komunikasi kependidikan lainnya. Dengan demikian, dapat dikatakan bahwa kepemimpinan yang efektif berkaitan erat dengan karakter pemimpin, penataan lembaga, hubungan sosial dan pencapaian kerja.

2. Kepempinan Kepala Madrasah

19 Blake R. R \& Mouton, The Managerial Grid III: The Key To Leadership Excellence, (Houston: Gulf Publishing, 1985), hal. 14 
Seorang pemimpin, baik dilembaga pendidikan maupun non pendidikan, harus merupakan orang yang memiliki banyak kemampuan. Dalam konteks lembaga pendidikan, kepala Madrasah sebagai pimpinan tertinggi memiliki beberapa peran dan fungsi. Sejatinya kepala Madrasah merupakan seorang tenaga fungsional guru yang diberikan tugas tambahan untuk memimpin suatu lembaga Madrasah yang di dalamnya berlangsung proses belajar mengajar. $^{20}$

Berdasarkan pemahaman ini maka pimpinan Madrasah harus memainkan beragam peran yang berkaitan aspek leadership dan manajerial. Dua peran ini harus dapat dijalankan secara proporsional dan kondisional. Melalui aspek leadership, kepala Madrasah harus dapat memberikan kebijakan yang tepat, capat dan visioner. Namun melalui aspek manajerialnya, kepala Madrasah harus dapat memastikan bahwa seluruh kebijakan yang dibuatnya dapat dilakukan oleh bawahanya pada tataran teknis. Konsep ini harus difahami dengan benar oleh seorang pemimpin dalam rangka menghindar dari terjadinya kebijakan yang tumpul. Kepala Madrasah merupakan orang yang bertanggung jawab secara moril terhadap keberlangsungan proses belajar mengajar di Madrasah secara efektif. Sedangkan secara kelembagaan, kepala Madrasah memiliki tanggung jawab untuk dapat menjalankan seluruh fungsi dari struktur lembaganya. Tanggung jawab moril dan struktural ini tidak lepas dari fungsi dirinya sebagai seorang [1] Educator, [2] Manager, [3] Administrator, [4] Supervisor, [5] Leader, [6] Innovator dan [7] Motivator. ${ }^{21}$

Besarnya tanggung jawab kepala Madrasah tersebut harus diimbangi dengan kompetensi yang harus dipersiapkan sebelum ia menjabat sebaga kepala Madrasah. Dimana, menurut Permendiknas No. 13 Tahun 2007 tentang Standart Kepala Madrasah/Madrasah, terdapat 5 kompetensi yang harus dipenuhi, yaitu, [1] Kompetnsi Kepribadian, [2] Kompetensi Sosial, [3] Kompetensi Supervisi, [4] Kompetensi Wirausaha, [5] Manajerial. Sejatinya, lima kompetensi dasar ini merupakan skil tambahan yang harus dimiliki oleh

\footnotetext{
${ }^{20}$ Siti Nurbaya, Gaya Kepemimpinan Kepala sekolah dalam meningkatkan Kinerja Guru pada SDN Lambaro Angan, (Jurnal Administrasi Pendidikan, Vol. 3, No. 2, Mei 2015), hal. 120

21 Siti Nurbaya, Gaya Kepemimpinan Kepala sekolah...hal. 120
} 
kepala Madrasah di samping ia sebagai guru. Dalam pelaksanaanya, kepemimpinan efektif di Madrasah dapat disederhankan menjadi sebuah pengertian bahwa kepemimpinan kepala Madrasah yang efektif adalah yang dapat menjalankan tugas, fungsinya sesuai dengan kompetensi yang ia miliki. Dimana, keseluruhan proses tersebut diorientasikan pada pencapaian prestasi akademik dan non akademik. Sehingga kepemimpinan efektif adalah kepemimpinan yang menfokuskan pada pengembangan intraksional, organisasional, staf, layanan murid dan komunikasi terhadap masyarakat.

Menurut Duignan, kepemimpinan kepala Madrasah efektif harus memiliki lima standart kapabilitas, yaitu: ${ }^{22}$

a. Educational capabilities: Kemampuan ini merupakan syarat utama bagi kepala Madrasah untuk memelihara fokus perhatian terhadap proses belajar mengajar.

b. Personal Capabilities: Kemampuan untuk menjadikan dirinya sebagai model, yang menjadi acuan tindakan dari seluruh elemen Madrasah.

c. Relational capabilities: Kemampuan yang mendasari pola hubungan antara kepala Madrasah dengan seluruh stakeholder diMadrasah.

d. Intelectual capabilities: Kemampuan ini mendasari akan pandanganpandangan kepala Madrasah terhadap kebijakan dan aktiftias organisasi yang hendak dicapai.

e. Organizational capabilities: Kemampuan dalam mengendalikan aspek managerial dengan pertimbangan efektiftias, efesiensi dan produktifitas.

3. Indikator Kepemimpinan Kepala Madrasah Efektif

Capaian praktik kepemimpinan tidak dapat dilihat dari satu aspek kepemimpinan, melainkan harus dilihat dari satu kesatuan yang utuh. Aspek pembelajaran, manajerial, leadership merupakan dimensi kepemimpinan kepala Madrasah yang harus dilihat dan dievaluasi capaiannya. Berikut ini

22 Joanne Eunice Dorothy Agtha, Kemampuan Relasional Kepala Sekolah dalam Penerapan Kepemimpinan distributif di Sekolah, A Journal of Language, Literature, Culture and Education, POLYGLOT Vol. 11, No. 4, Oktober 2015, hal. 21 
adalah indikator kepemimpinan kepala Madrasah efek yang dapat dijadikan tolak ukur capaian: ${ }^{23}$

a. Berpegang dan menjadikan visi, misi Madrasah sebagai pedoman dan rujukan praktik kepemimpinan.

b. Memiliki komitmen yang tinggi terhadap aspek KBM dan pengembangan tenaga kependidikan.

c. Tekun mengamati aktiftias KBM yang dilakukan oleh guru di Madrasah dan memberikan dukungan yang konstruktif.

d. Mendorong pemanfaatan waktu secara efesien dan produktif.

e. Mampu memanfaatkan sumber daya secara kreatif.

f. Melakukan pemantauan terhadap prestasi siswa secara individu dan kelompok untuk tujuan perencanaan instruksional.

Indikator ini merupakan implementasi dari tugas kepala Madrasah sebagai seorang supervisor yang berkaitan dengan KBM. Namun disisi lain juga terdapat beberapa indikator kepemimpinan yang berkaitan dengan aspek manajerial. Berikut ini adalah beberapa indikator yang secara langsung menyentuh aspek manajerial. ${ }^{24}$

\section{KESIMPULAN}

Kepemimpinan merupakan seni memengaruhi orang, seni menggerakan orang dengan memanfaatkan sumberdaya demi mencapai tujuan. Pemahaman ini memberikan dua makna yang perlu di urain. Pertama, seni, jika kepemimpinan merupakan seni, maka dapat dipastikan setiap orang memiliki cara tersendiri untuk mengekspresikannya. Kedua, orang lain, jika kepemimpinan harus melibatkan orang lain, maka kewajiban utamanya adalah mengamati, memperhatikan kondisi orang lain. Oleh sebab itulah maka penguatan kepemimpinan merupakan suatu diskurusus antara siapa diri kita dan bagaimana orang lain. Pemahaman ini memberikan konsekwensi logis bahwa cara, gaya model tipe kepemimpinan akan berbeda antara satu orang dengan lainnya. Efektifitas kepemimpinan dalam meningkatkan kualitas pendidikan tergantung

23 Yantoro, Kepemimpinan Kepala Sekolah dalam Mengembangkan Sekolah Efektif, Jurnal Penelitian Univeristas Jambi,, Vol. 14, No. 01, 2013), hal. 61

24 Yantoro, Kepemimpinan Kepala Sekolah dalam Mengembangkan Sekolah Efektif, hal. 62 
pada bagaimana gaya kepemimpinan seseorang disesuaikan dengan keadaan atau situasi. Jika gaya yang digunakan oleh pemimpin sesuai dengan situasi, maka kepemimpinannya akan efektif dan begitu sebaliknya. Berdasarkan premis-premis tersebut dapat dikatakan bahwa tidak ada satupun dari kepemimpinan efektif yang dicapai dengan satu pendekatan, model, tipe kepemimpinan, melainkan harus dipadu dengan gaya dan model lainnya yang relevan dengan kondisi bawahannya. Oleh sebab itu, maka konsep mengenai teori kepemimpinan situasional dapat dijadikan sebagai pendekatan dalam menjalankan praktik kepemimpinan di Madrasah. Mengingat, konsep ini memberikan legitimasi terhadap ragam gaya yang dapat digunakan dalam situasi tertentu.

\section{DAFTAR PUSTAKA}

Asnawan, Enhancement Integrated Quality Management in Islamic Education Institutions (Peningkatan Manajemen Mutu Terpadu di Lembaga Pendidikan Islam ), Vol. 1, No. 1, January 2021, View of Enhancement Integrated Quality Management in Islamic Education Institutions (attractivejournal.com)

Abd. Wahib, Urgensitas Manajemen Lembaga Dalam Meningkatkan Kepercayaan Masyarakat, Jurnal Falasifa, Vol. 11 Nomor 1 Maret 2020, Vol 11 No 1 (2020): MARET | FALASIFA : Jurnal Studi Keislaman (inaifas.ac.id)

Blake R. R \& Mouton, The Managerial Grid III: The Key To Leadership Excellence, (Houston: Gulf Publishing, 1985)

Judy Reinhartz dan Don M. Beach, Educational Leadership: Changing Schools, Changing Roles, Pearson Education, Inc: USA, 2004.

James L. Gibson, et.al, Organisasi, Jilid 1 (Jakarta: Erlangga, 1996).

Joanne Eunice Dorothy Agtha, Kemampuan Relasional Kepala Sekolah dalam Penerapan Kepemimpinan distributif di Sekolah, A Journal of Language, Literature, Culture and Education, POLYGLOT Vol. 11, No. 4, Oktober 2015.

Gordon Dryden dan Jeannette Vos, Revolusi Cara Belajar: Sekolah Masa Depan, Bandung, Kaifa, 2000.

Gary Yukl, Kepemimpinan dalam Organisasi (Jakarta: PT. Indeks, 2005).

AF Stoner dkk, Manajemen, Jilid II (Jakarta: PT Prenhallindo, 1996). 
Stephen P. Robbins, Prilaku Organisasi: Konsep, Kontroversi, Aplikasi, Jilid 2 (Jakarta: PT Prenhallindo, 1996).

Kartini Kartono, Pemimpin dan Kepemimpina, (Jakarta: PT. RajaGrafindo Persada, 1998)

Veithzal Rivai, Pemimpin dan Kepemimpinan dalam Organisasi, (Jakarta: Rajawali Press, 2014)

Siti Nurbaya, Gaya Kepemimpinan Kepala sekolah dalam meningkatkan Kinerja Guru pada SDN Lambaro Angan, (Jurnal Administrasi Pendidikan, Vol. 3, No. 2, Mei 2015).

Yantoro, Kepemimpinan Kepala Sekolah dalam Mengembangkan Sekolah Efektif, (Jurnal Penelitian Univeristas Jambi, Vol. 14, No. 01, 2013) 